\title{
As probas de exame para ocupar o posto de directora na Escola Normal de Mestras de Ourense. 1880
}

\author{
Rosa María CID GALANTE \\ Doutora en Xeografía e Historia \\ Licenciada en Psicopedagoxía
}

A mediados do século XIX comezan a xurdir as Escolas Normais en España. A creación dunha Institución na que se formasen a mestras e mestres tivo unha importante repercusión na educación primaria xa que estes novos docentes acreditarían unha mellor ensinanza aos nenos e nenas. Arrincando o novo século, García Alix e Romanones estarían ao fronte do Ministerio de Instrución Pública de Belas Artes acometendo as reformas das Escolas Normais co interese de formar aceptablemente aos futuros ensinantes. As primeiras Normais tiñan a súa propia sé, mais a comezos do século XX intégranse nos Institutos Provinciais por razóns de tipo económico xa que as Normais eran difíciles de manter polo Estado.

En Ourense creáronse a Normal de Mestres no ano 1842 e a de Mestras en 1877. Esta última tivo un proceso longo de creación debido aos pertinentes trámites polos que tivo que pasar e que supuñan a intervención da Xunta Provincial de Ourense, o Reitor de Santiago e mais a Deputación Provincial que era a Institución que debía manter dito Centro. No proceso da creación da Normal en Ourense, unha das cuestións principais que lle formulaba a Deputación Provincial ao Reitor de Santiago versaba sobre o nomeamento da Dirección. Na misiva que lle envía dicía literalmente:

\footnotetext{
Para dar cumplimiento a la Real Orden de 6 del actual, por la que se autoriza a la Exma. Diputación provincial para crear una escuela Normal de Maestras, esta Junta por lo que a si toca, se halla que la RO. de 14 de Marzo de 1877 vigente en esta materia, ofrece las siguientes dudas:

$1^{\mathrm{o}}$ - Que autoridad o Corporación debe anunciar las oposiciones para el nombramiento de Directora.

$2^{\circ}$.- Ante quien deben presentar las solicitudes las aspirantes.

$3^{\circ}$.- Quien es la persona llamada a desempeñar el cargo de Secretario del Tribunal de Oposiciones.

$4^{\mathrm{o}}$.- No habiendo en la capital más que una maestra de escuela pública con título superior, y exigiendo la RO completar el tribunal ¿Puede ser nombrada otra que reúna las condiciones en la provincia?

Lo que esta Junta en sesión de 24 del actual, acordó consultar con VE rogándole tenga a bien resolver lo que en su superior ilustración considere más acertado ${ }^{1}$.
}

\footnotetext{
${ }^{1}$ AHUS. Expediente de creación de la Escuela Normal de Orense. Sección Histórica. Leg. 446.
} 
O Reitor, dando resposta inmediata a esta demanda indicou os requisitos que debían ter as candidatas para presentarse á oposición e ocupar dito posto. Así pois, as aspirantes debían presentar á Institución Provincial os seguintes documentos: ter o Título de mestra de Ensinanza Superior; a partida de bautismo xustificando que a interesada tiña cumpridos vinte e un anos; certificación de boa conduta; fe de casada se o fose; relación por orde de numeración dos labores que debían presentar sen rematar e sen lavar nin pasar o ferro, para continualas en presenza do Tribunal e, finalmente, presentar unha lámina de debuxo lineal en papel marquilla tamén a medio facer para ser concluída diante do Tribunal. Presentados estes documentos, a opositora, debía realizar os exercicios teóricos e prácticos.

Estaba regulado polo Real Decreto do 11 de agosto de 1887 que as mestras que obtiveran o título de Profesoras Normais na Central podían aspirar a ser Directoras presentándose aos exercicios pertinentes ante un Tribunal. As que conseguían a praza permanecerían seis anos e, rematado este prazo, podían ser confirmadas unha ou máis veces por igual tempo ${ }^{2}$. Segundo a RO do 9 de decembro de 1887 os Directores das Escolas Normais de Mestres e as Directoras das Escolas Normais de Mestras levarían un distintivo que consistía nunha medalla de ouro mentres que o resto de profesores e profesoras das Normais portarían unha medalla de prata. A cor do cordón que suxeitaba a medalla sería para o profesorado das Normais, vermello, celeste e turquí. As Directoras tiñan o cargo da inspección, coidado das alumnas e o réxime interior do establecemento. Hai que dicir que as Escolas Normais de Mestras non gozaban da mesma categoría que a de Mestres; por tal motivo, Dona Rosario García González, directora da Escola Normal de Córdoba, diríxese o 1 de xaneiro de 1888 ao Exmo. Sr. Ministro de Fomento, en nome das directoras das Normais de España, entre elas a de Ourense, para solicitar que fosen declaradas as Escolas Normais de Mestras como profesionais, como así eran a de Mestres, e tamén que as Directoras percibisen o mesmo soldo que os seus homólogos ${ }^{3}$. Algo que non chegou a resolverse pois nos anos vindeiros reincidíase nesta solicitude.

No Expediente de creación da Escola Normal de Mestras de Ourense atopado no Arquivo Histórico da Universidade de Santiago, sección histórica $n^{0} 446$, incorporáronse os exames realizados entre o 15 e o 19 de outubro de 1880 polas tres postulantes á Dirección: Dona Carmen Rogina; Dona Iluminada Prieto de la Cal e Dona Ramona Pérez Acedo; e neles figuran as cuestións que se lle planteaban e as respectivas respostas. Son unha fonte de primeiro orde para coñecer o nivel esixencia para cubrir un posto tan relevante. Conseguir estas fontes primarias supoñen para os investigadores da historia da educación un importante logro, xa que, ademais de permitir a reconstrución do proceder do exame, achéganos á propia mentalidade da época, pois, tanto as cuestións formuladas ás mestras

\footnotetext{
${ }^{2}$ Boletín de primera enseñanza de la provincia de Gerona Año XIII Número 35 - 1887 agosto 30.

${ }^{3}$ Boletín de primera enseñanza de la provincia de Gerona Año XIV Número 4 - 1888 enero 24
} 
para ocupar o posto da Dirección da Normal, como as súas respostas, denotan os principios socioculturais e morais que rexían no momento e que, sen dúbida, eran de maior esixencia para as mulleres.

A continuación detállanse as preguntas do exame que se lles formularon ás tres mestras que optaban á praza de Dirección. A proba escrita e teórica estaba estruturada en dúas partes. Logo había a parte práctica que consistía en rematar os debuxos, bordados e prendas para pasar o ferro diante do Tribunal.

\section{$1^{\circ}$ Ejercicio:}

Catecismo explicado de Doctrina

$\mathrm{N}^{0}$ 8. Expliquen las siete peticiones del padrenuestro que se llama oración dominical, es decir, del Señor ¿Por qué?

$\mathrm{N}^{\mathrm{o}}$ 13. Expliquen que es el Sacramento del Bautismo. ¿Para qué es? ¿Cómo y quién debe administrarlo de necesidad?

Historia Sagrada

$\mathrm{N}^{\circ}$ 17. Paso del Mar Rojo por el pueblo de Israel. Muerte de los egipcios que los perseguían.

No 21. ¿Quiénes han sido Saúl y David? Causas de reprobación del primero. Rasgos principales de David.

Gramática Castellana

No 17. Qué es elipses y cuál es su uso y utilidad. Ejemplos de ella.

№ 4. ¿Cuántos son los géneros de los nombres en la lengua castellana y por qué reglas nos guiamos para su aplicación? Algunos ejemplos.

Aritmética

$N^{0}$ 5. ¿Qué es multiplicar? Casos que pueden ocurrir en la multiplicación de los números y abreviaciones más usuales. ¿En qué relación se halla el multiplicando con el producto? Prueba de las multiplicaciones.

$\mathrm{N}^{\mathrm{o}}$ 14. Multiplicación de los quebrados y números mixtos. Casos que pueden ocurrir y como se resuelve la operación en cada uno de ellos.

Principios de educación y métodos de enseñanza

$\mathrm{N}^{\mathrm{o}}$ 1. Instrucción, su importancia y divisiones que de ellas se hacen. Diferencia entre ella y la educación.

$\mathrm{N}^{\mathrm{o}}$ 11. Método especial en la enseñanza de la Gramática Castellana. Extensión que debe darse a cada parte según el grado de la escuela. 


\section{$2^{\circ}$ Ejercicio.}

Geografía.

Elementos de Geografía general y Particular de España

$\mathrm{N}^{\mathrm{o}}$ 15. Meteoros: su explicación. Vientos.

No 30. Situación y límites de América

Historia de España

$N^{\circ}$ 9. Viriato y sus empresas contra los Romanos. Destrucción de Numancia

$\mathrm{N}^{\mathrm{o}} 13$. Religión, gobiernos y cultura de los godos

Geometría

$\mathrm{N}^{0}$ 9. ¿Cuantos ángulos rectos componen los tres de cada triángulo? ¿Por qué en el triángulo rectángulo y obtusángulo tienen que ser agudos los otros dos ángulos?

$N^{o} 11$ ¿Qué es romboide, rombo, rectángulo y cuadrado?

Economía Doméstica

$\mathrm{N}^{\mathrm{o}} 1$. ¿Cuáles son los deberes de la mujer?

$\mathrm{N}^{\mathrm{o}} 21$. ¿Son convenientes las velas de sebo para el alumbrado?

Higiene

$N^{o}$ 23. Enfermedades contagiosas, prevenciones para evitar el contagio.

$N^{o} 14$. De las bebidas

Nas preguntas sobre Doutrina Cristiá e Historia Sagrada as tres solicitantes amosan coñecementos profundos das cuestións relixiosas e bíblicas, denotando unha clara formación devota, tan ben estimado na moralidade da época e un requisito indispensable para a función docente..

En canto ás nocións de Aritmética, Gramática, Xeografía, Historia, as respostas son académicas e teóricas en base aos contidos memorizados.

Pero moi interesantes son as contestacións que as candidatas deron ás preguntas sobre os principios da educación e métodos de ensinanza pois son preguntas contestadas libremente segundo o criterio particular das opositoras. Todas elas aluden á importancia da educación e a instrución, para Carmen Rogina, porque reportan beneficios para a prosperidade dos pobos; para Iluminada Prieto porque permiten o desenvolvemento da intelixencia; e para Ramona Pérez, indica que a instrución é importante para todos pero especialmente para a muller. Recóllese a continuación un fragmento de cada unha das mestras candidatas sobre o que indican da educación e a instrución: 
"Instrucción es la parte de la Pedagogía que tiene por objeto la aplicación de los medios más a propósito para enriquecer la inteligencia con conocimientos útiles. Esta se diferencia de la educación en que desarrolla lo que en hombre existe, y la segunda le proporciona lo que no posee. La primera que es la instrucción se ocupa de la adquisición de conocimientos y la segunda del desarrollo de las facultades. La educación y la instrucción se auxilian mutuamente... La educación e instrucción influyen notabilísimamente en las costumbres y prosperidad de los pueblos..."

"Instrucción es un conjunto de conocimientos de utilidad con que ilustramos nuestra inteligencia y por eso se dice que instruir es poner en desarrollo las facultades intelectuales por medio de conocimientos útiles. La instrucción es tan importante que sin ella no habría pueblos civilizados....La instrucción ha de ser general...La educación y la instrucción tienen puntos de contacto...educar es poner en desarrollo todas las facultades del hombre; las físicas, las morales y las intelectuales. Instruir es poner en desarrollo las facultades intelectuales haciendo al mismo tiempo que la inteligencia adquiera conocimientos..."

"La Instrucción es sumamente importante para todas las clases de la sociedad; pero lo es esencialmente para la mujer porque elegida por el Supremo Hacedor para ser el primer mentor de la niñez, no debe carecer de los conocimientos necesarios para educar e instruir a sus hijos. La instrucción debe ser general y abrazar todas las asignaturas...La instrucción es el complemento de la educación, advirtiendo que la primera no puede subsistir sin la segunda, sirviéndonos para la otra vida porque nos enseña el buen modo de arreglar nuestras acciones con los preceptos del decálogo...”

Outro aspecto interesante sobre o que se lles pregunta é o relativo á metodoloxía didáctica, en concreto na Gramática. Elas demostran ter bastante claro o procedemento que van seguir. Unha delas fai alusión a que o método que empregará será o método interrogativo, que á súa vez se divide en dialogísticosocrático e catequístico. Explica que o "dialogístico-socrático” é cando se pregunta aos nenos indirectamente ata que cheguen a comprender o contido; o "método catequístico" é cando se pregunta sobre o que se lle ensinou. Á súa vez os métodos divídense en xerais, é dicir, aplicables a todos os nenos, e particulares cando se aplican a un só. Outra das candidatas tamén fai alusión ao "método interrogativo" e engade o "intuitivo". En canto á terceira candidata non especifica os tipos de métodos que aplicará na aula e limítase a indicar o procedemento para explicar a gramática.

Pero especialmente ricas son as respostas dadas ás cuestións de Economía Doméstica pois é aquí onde se concentra toda a mentalidade referente ao rol que se lle vén esixindo á muller nesta época e que estas candidatas teñen ben asumido.

"Los deberes de la mujer es arreglar de tal manera su conducta que aparezca a los ojos de todos como modelo de honradez y religiosidad. La mujer tiene la obligación de administrar el gobierno interior de la familia, para el buen régimen de la casa, formar su corazón, animar y soportar al marido en sus empresas para que no desfallezca y del hogar doméstico haya la dicha y el bienestar; si tiene familia debe procurar que sus hijos y en particular las hijas, desempeñen cualquier ocupación..."

"Los deberes de la mujer son tantos y de tan distintas condiciones según su estado, que será preciso limitar a los que tiene como ama de casa; en cuyo caso los principales son los siguientes: físicas, religiosas y morales y intelectuales y sociales o de sociedad. Físicas tiene el deber de cuidar de la salud de todos los individuos de su familia....Ha de inculcar en todos los 
miembros de su familia las máximas y principios de moralidad y religión...De nada valen los consejos sin el ejemplo..."

"Los principales deberes de la mujer se reducen a tres principales: deberes con la familia, para con la sociedad y para consigo misma. Para con la familia tiene el deber de una fe y obediencia ciega a su marido y un entrañable cariño que jamás debe extinguirse...Para con sus hijos deberá prodigar sus desvelos, darles el sustento conveniente...Para con los criados deberá exigirles el exacto cumplimiento de sus deberes pero sin asediarles...Si hubiera entre la familia en el hogar doméstico algún pariente debe tratarlo con afabilidad, tolerar sus defectos...Ante la sociedad deberá la mujer presentarse como modelo de virtud, de honradez y de limpieza y huir de todas aquellas compañías que puedan perjudicarla en su reputación..."

Como pode apreciarse a proba era extensa, por iso se entende que as tres opositoras non realizasen os exercicios o mesmo día, senón que foron citadas en diferentes xornadas, o 15, 16 e 19 de outubro de 1880 .

A continuación reproducimos un dos exercicios revisados, concretamente o presentado por dona Carmen Rogina. Consta o documento de dezaoito follas manuscritas. As preguntas aparecen numeradas, aínda que non correlativamente, e eran ditadas oralmente á aspirante. De seguido, aparecen as repostas dadas a cada pregunta respectando o orden no que foron anotadas. Observarase que son respostas extensas e seguras, pois non aparecen correccións ou rectificacións. Finalmente aparece o exercicio práctico de costura, o de debuxo lineal e o de xeometría que debían rematar diante do Tribunal. 
Exame de Carmen Rogina Tejada, para a dirección da Escola Normal de Mestras de Ourense en 15 de outubro 1880

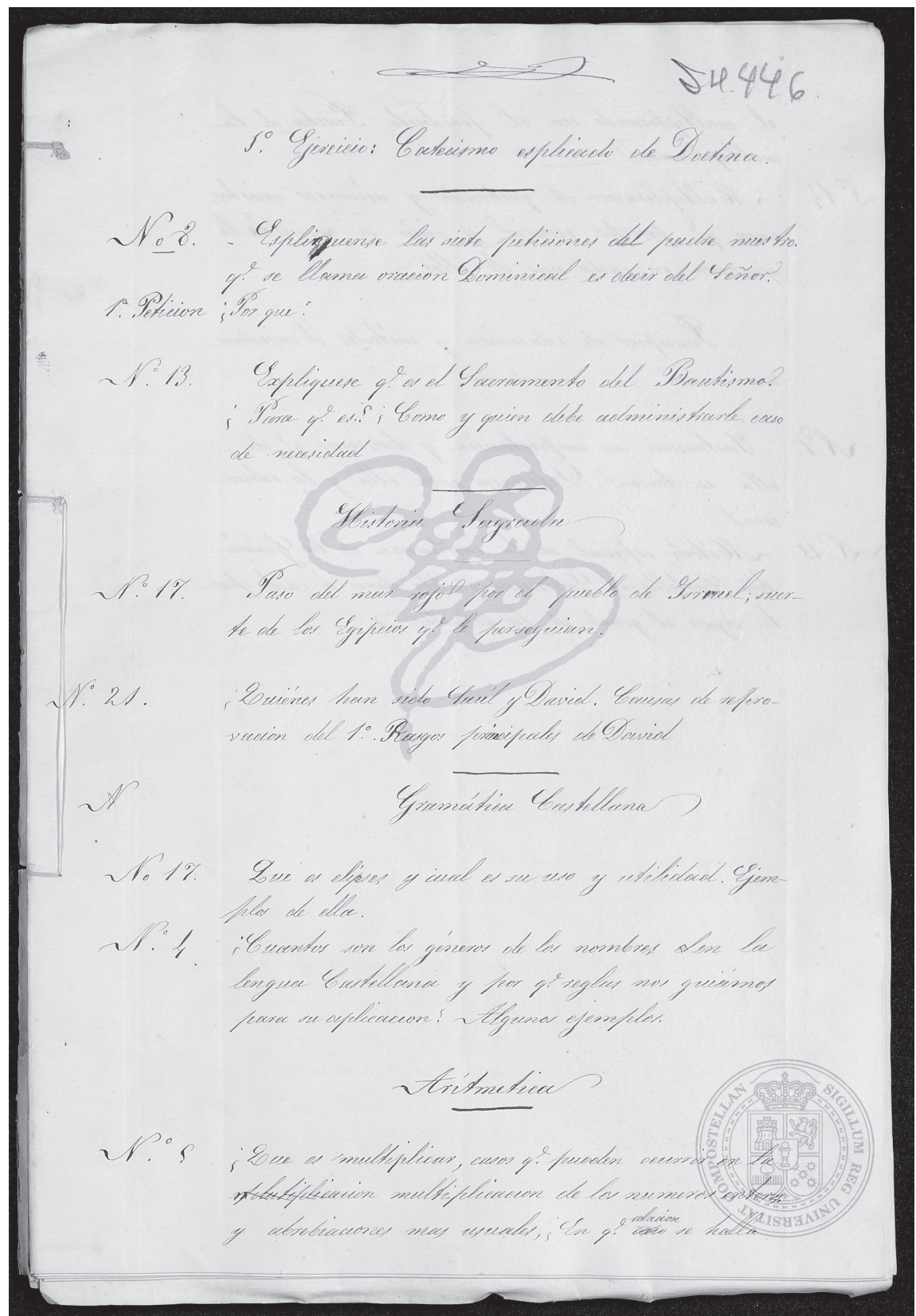




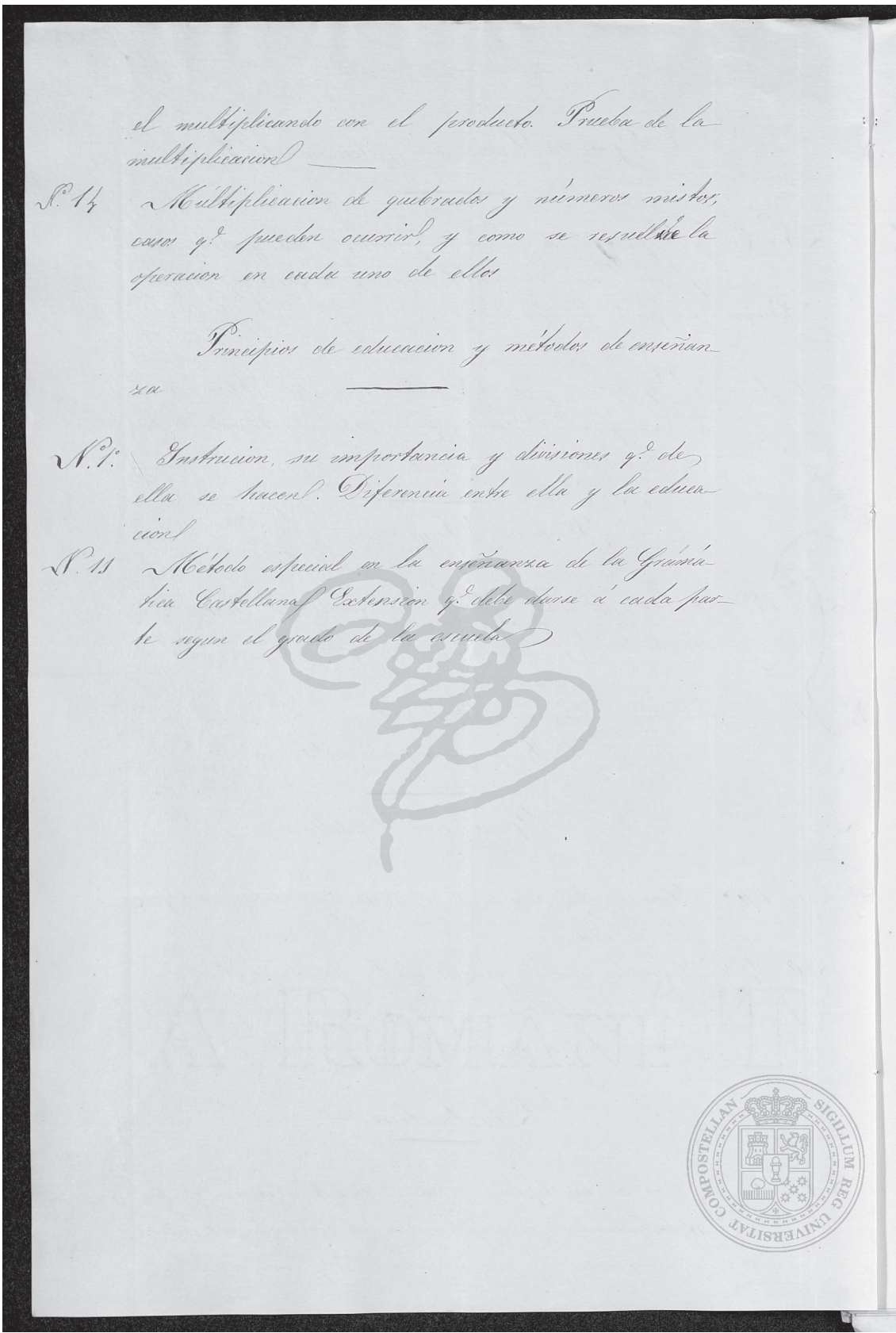




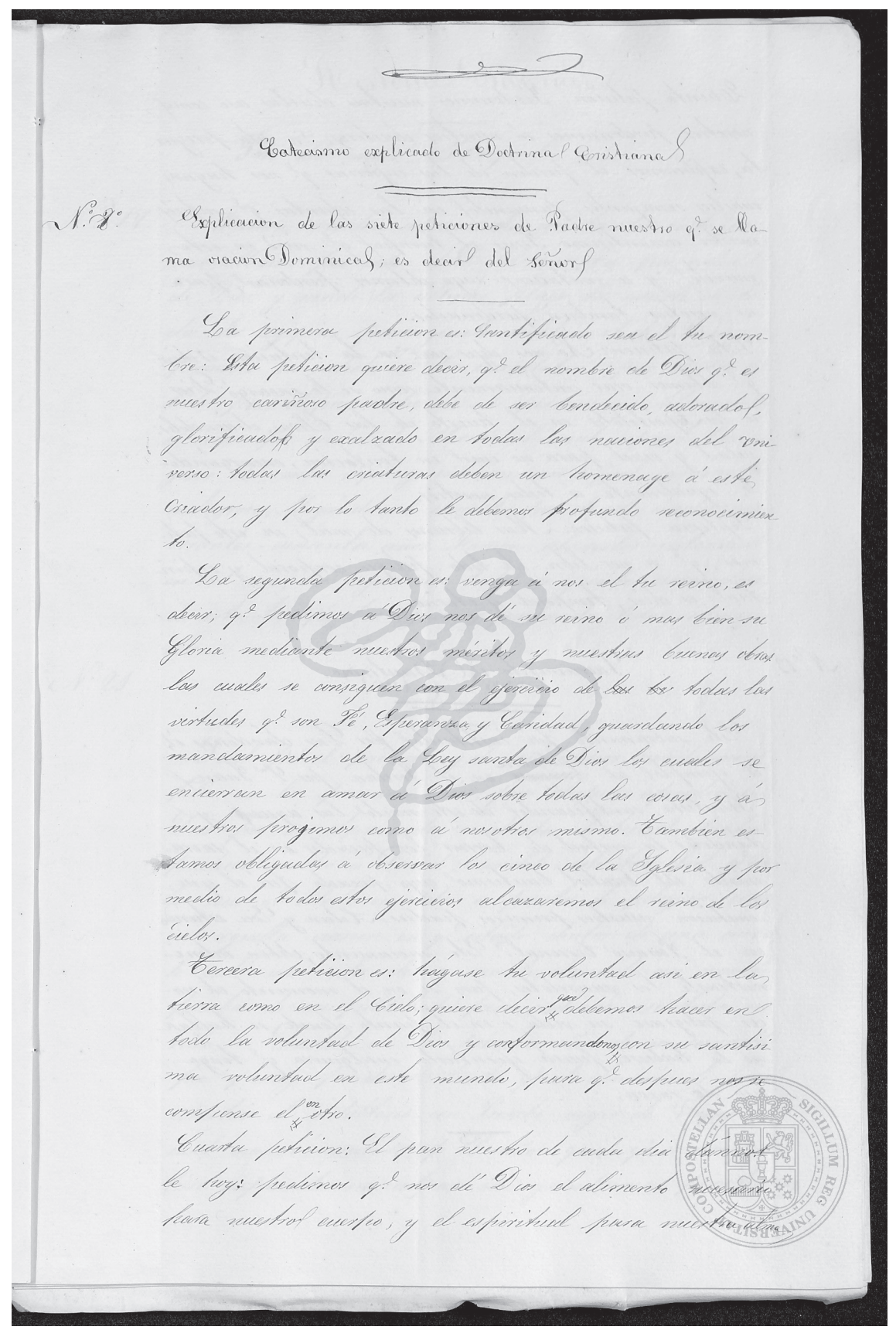




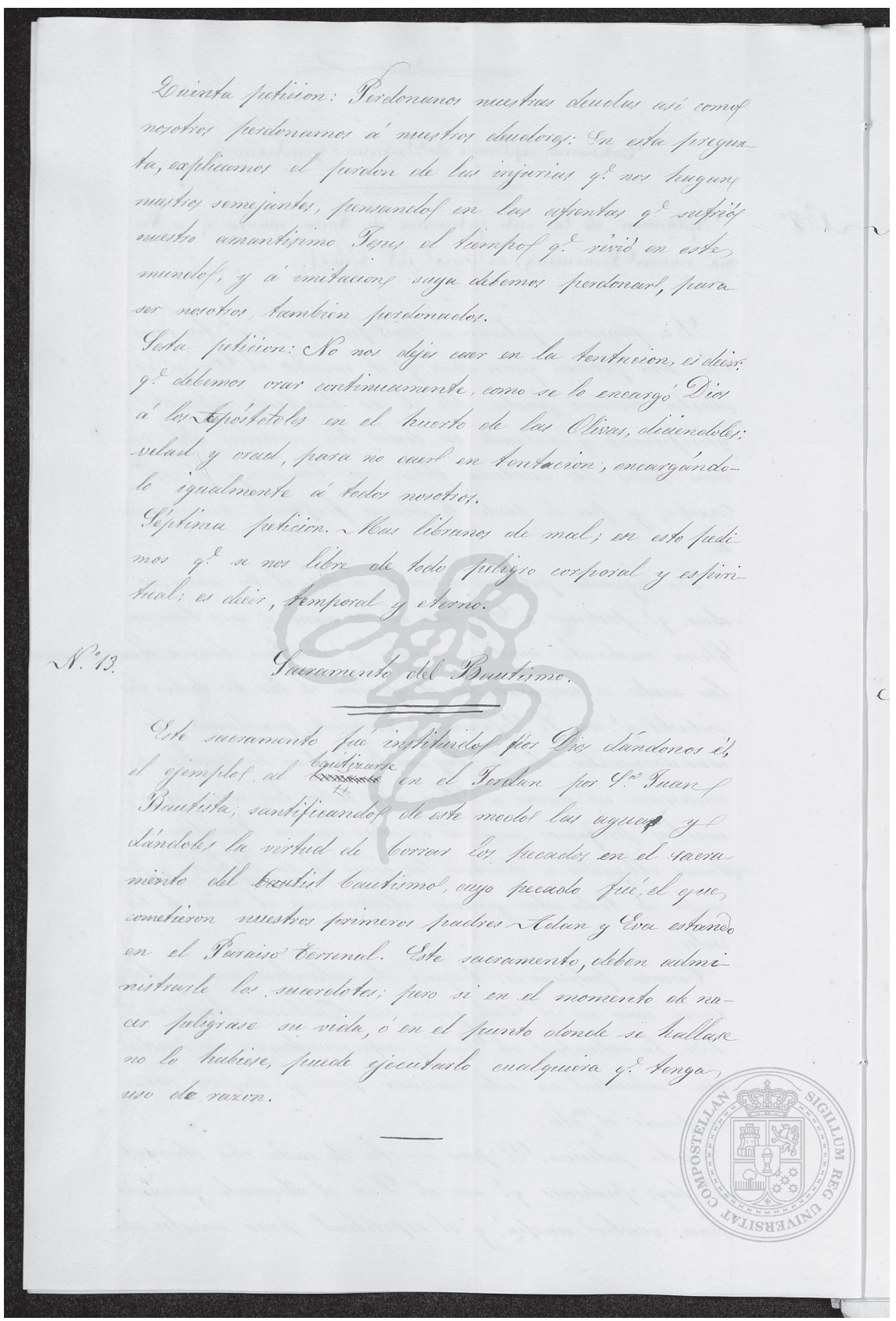




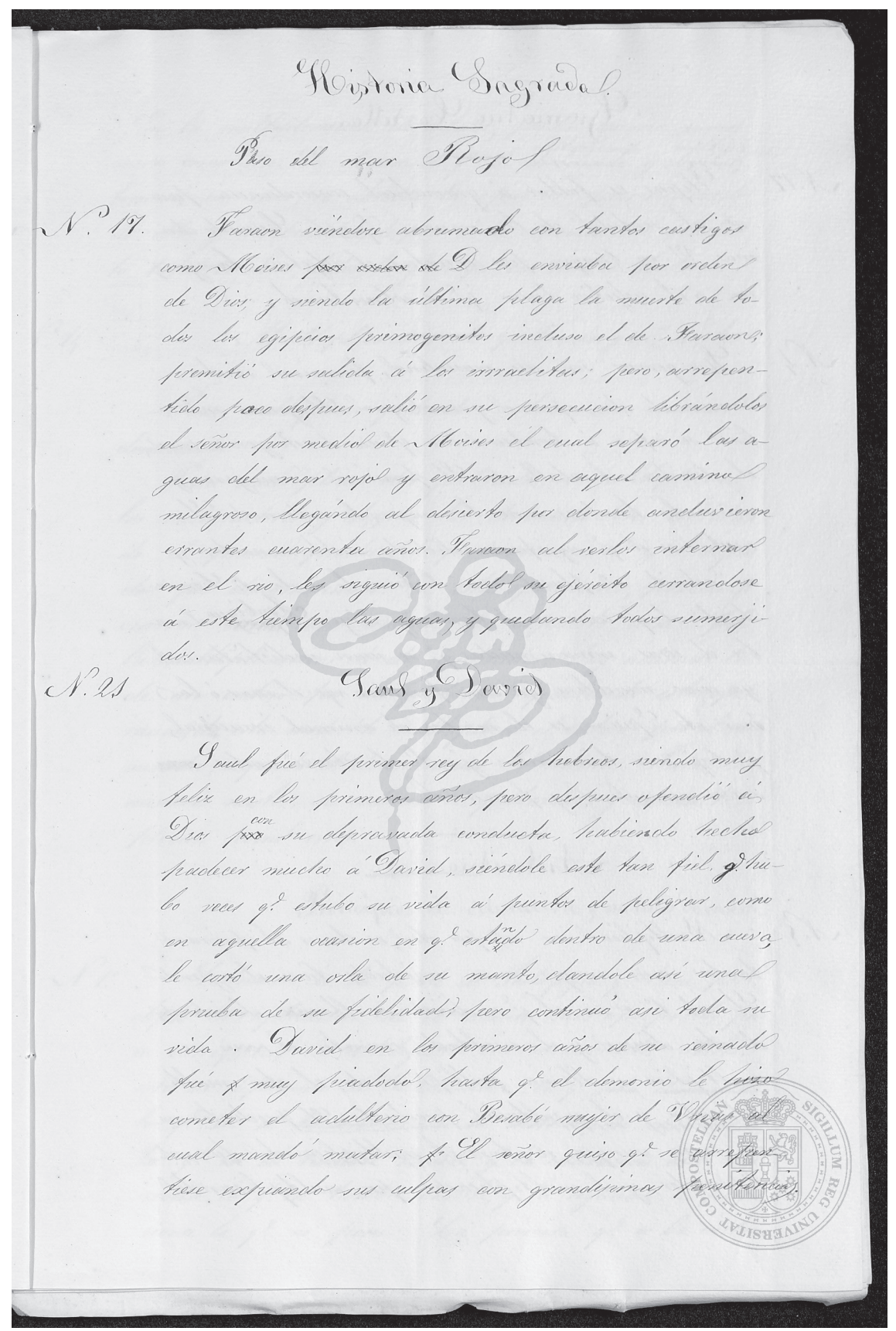




$$
\text { Cramaitica Castellana }
$$

W.YY

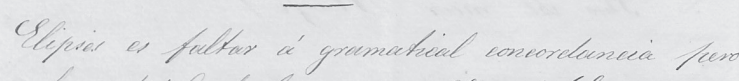

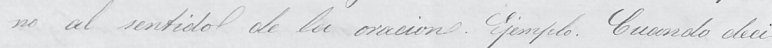

near 15. on benigno fur cuncertar el adfetesio hanigna

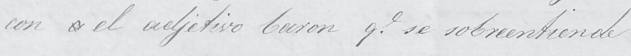

M.

$$
\text { Ser }
$$

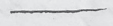

commen de das, efucienaly ambiguer. Sf genero masu

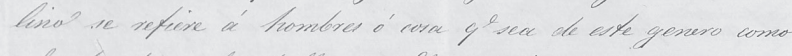

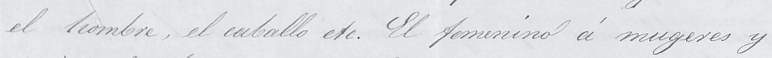

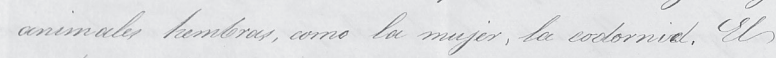

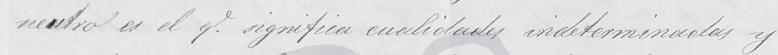

20 admite ne. felural como to bueno, to macto etc. Comme

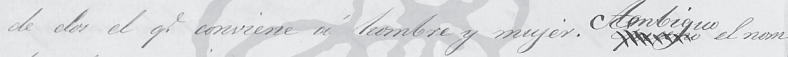

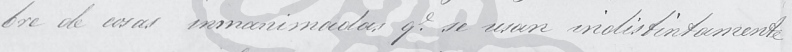

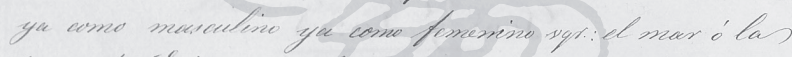

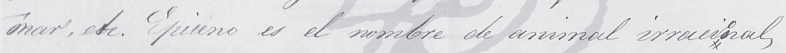

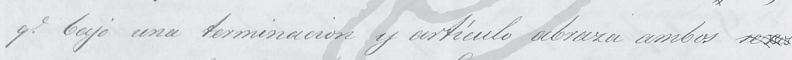

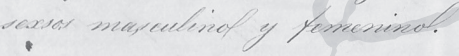

Tritméticar

U.

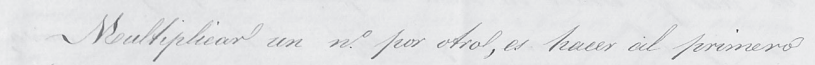

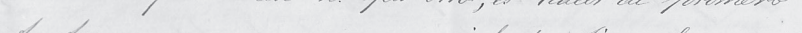

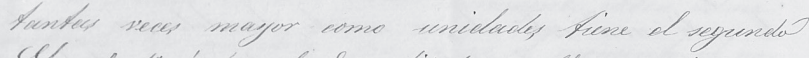

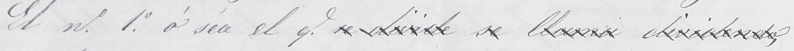

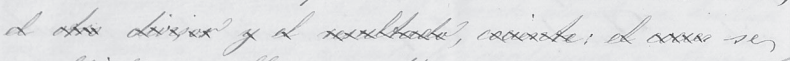

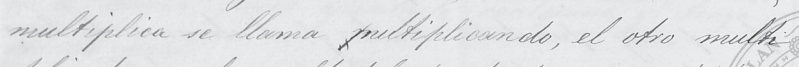

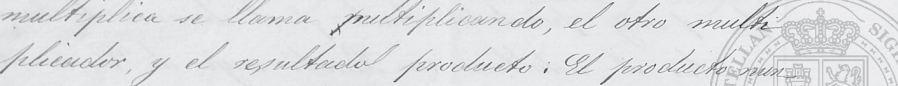

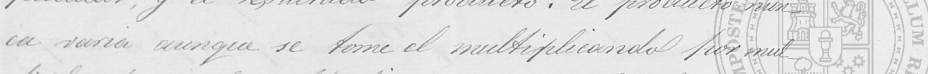

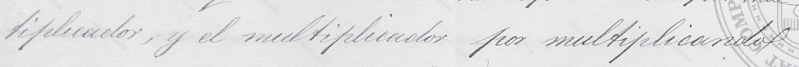




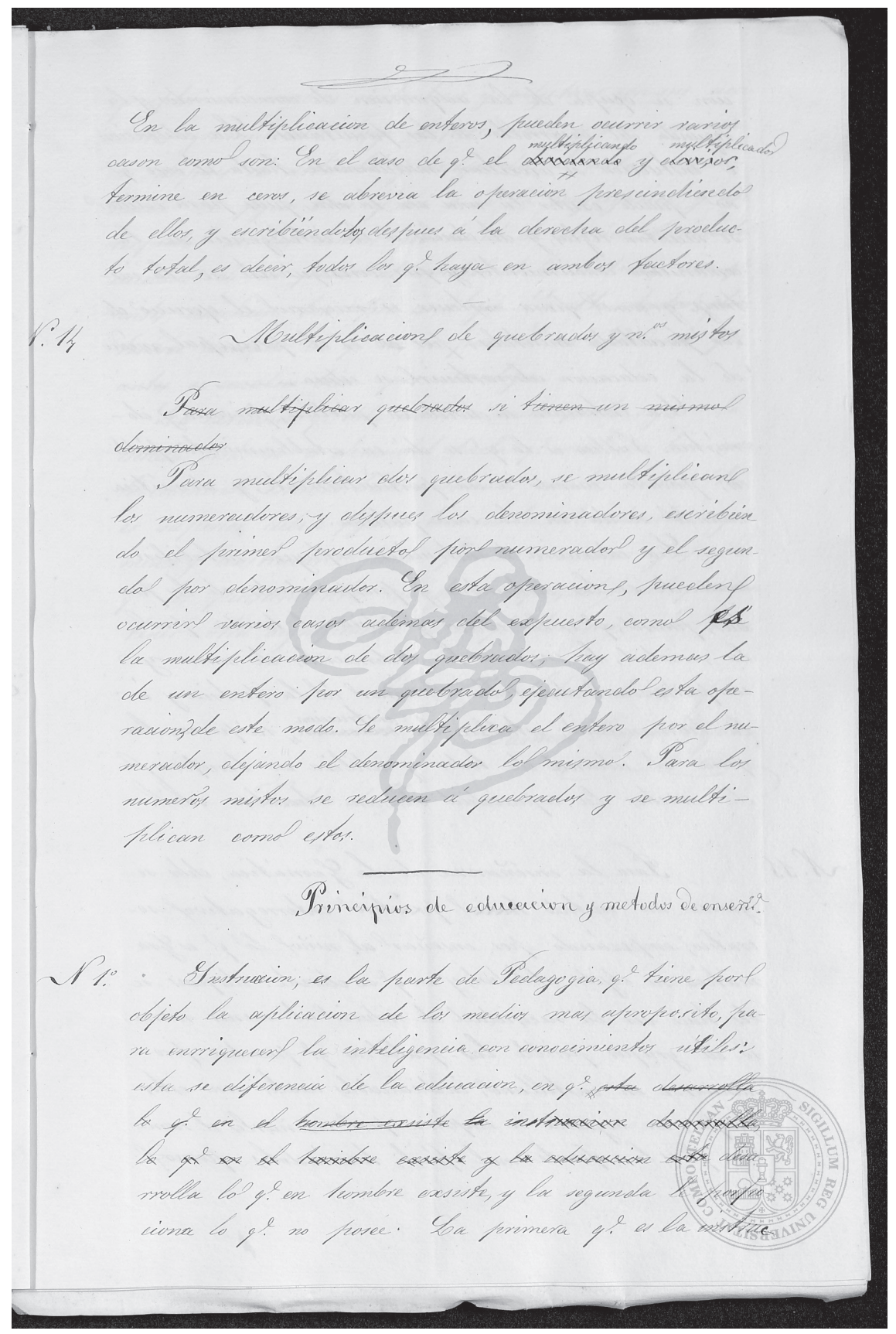




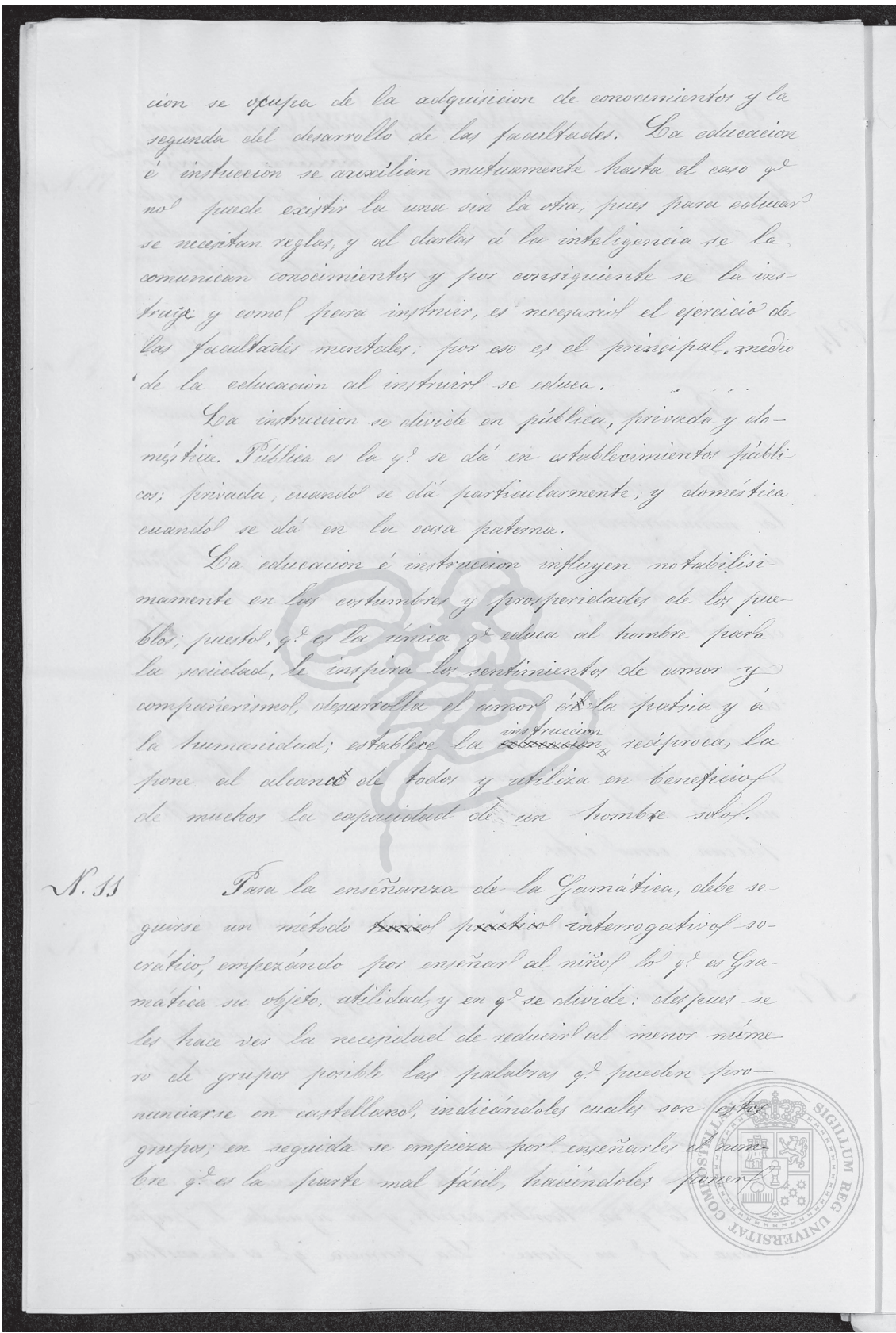




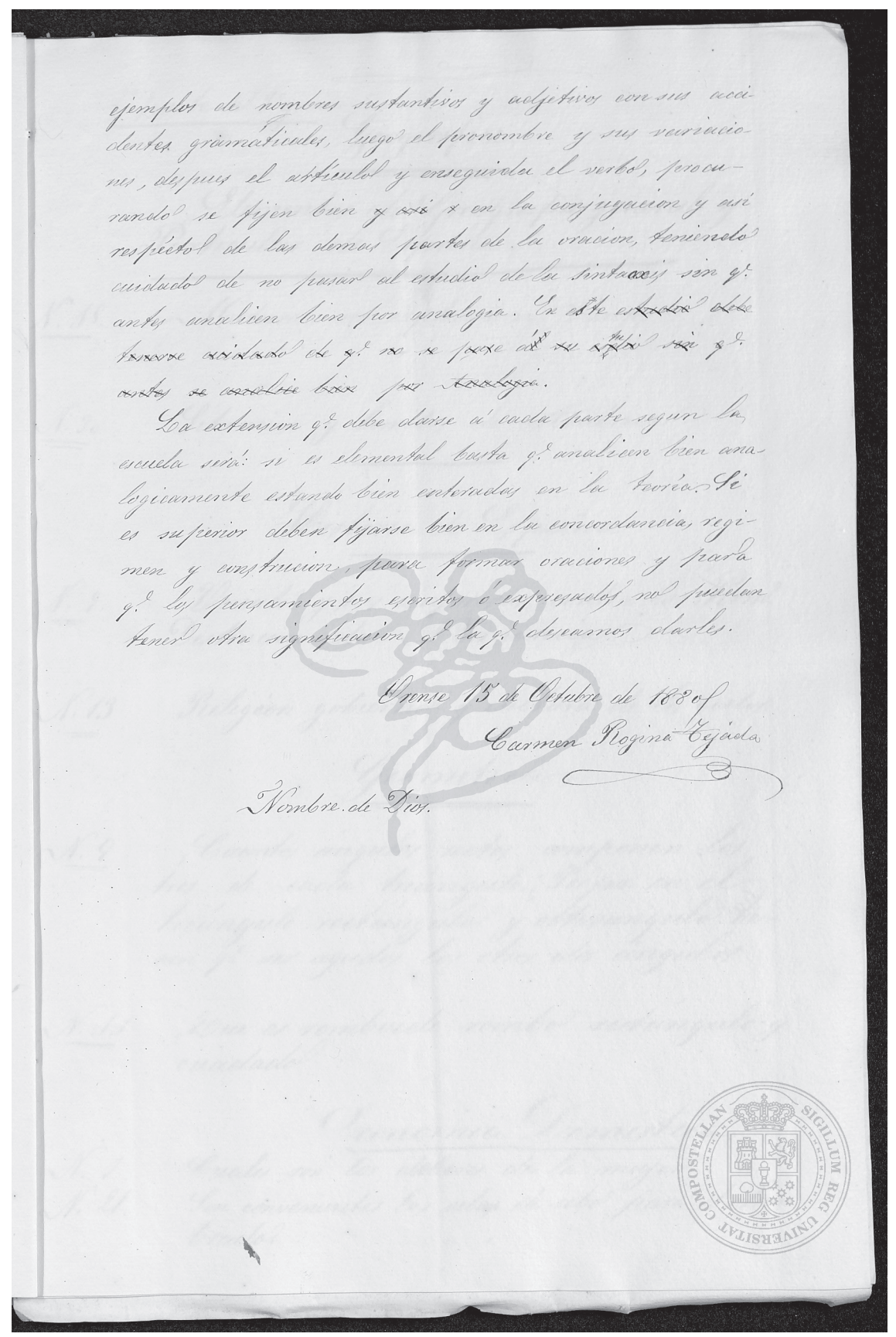




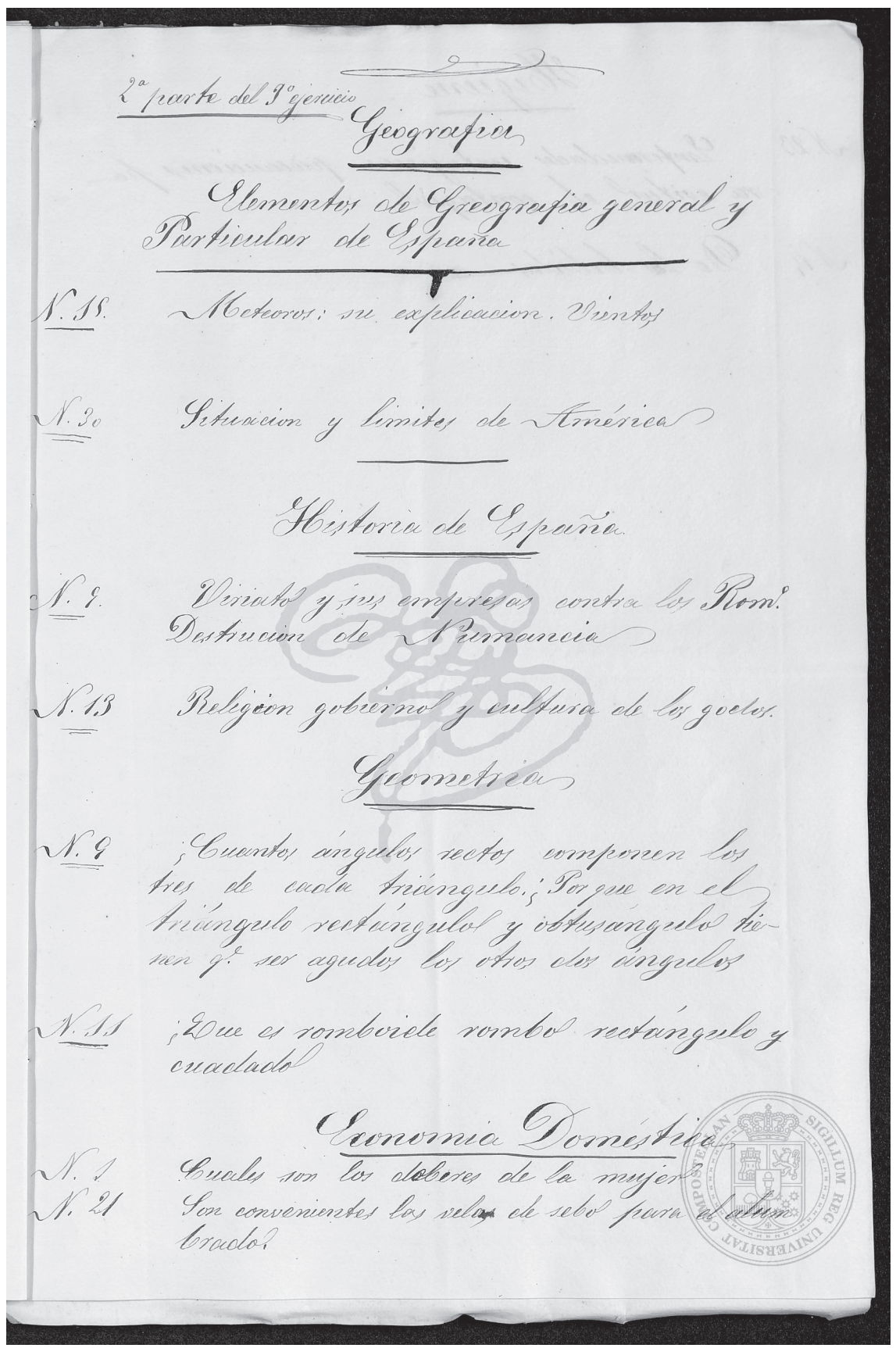




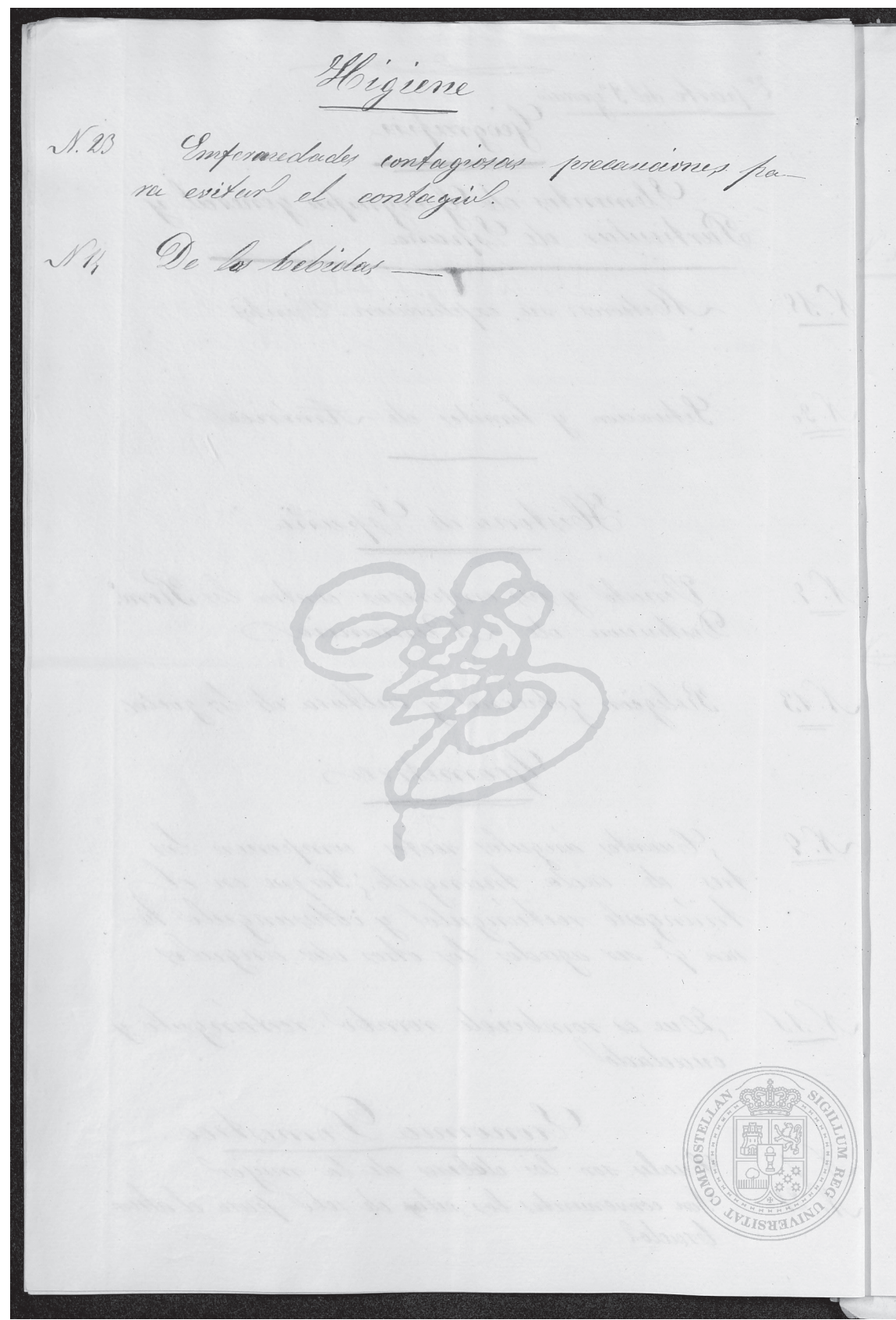

Sarmiento 243 


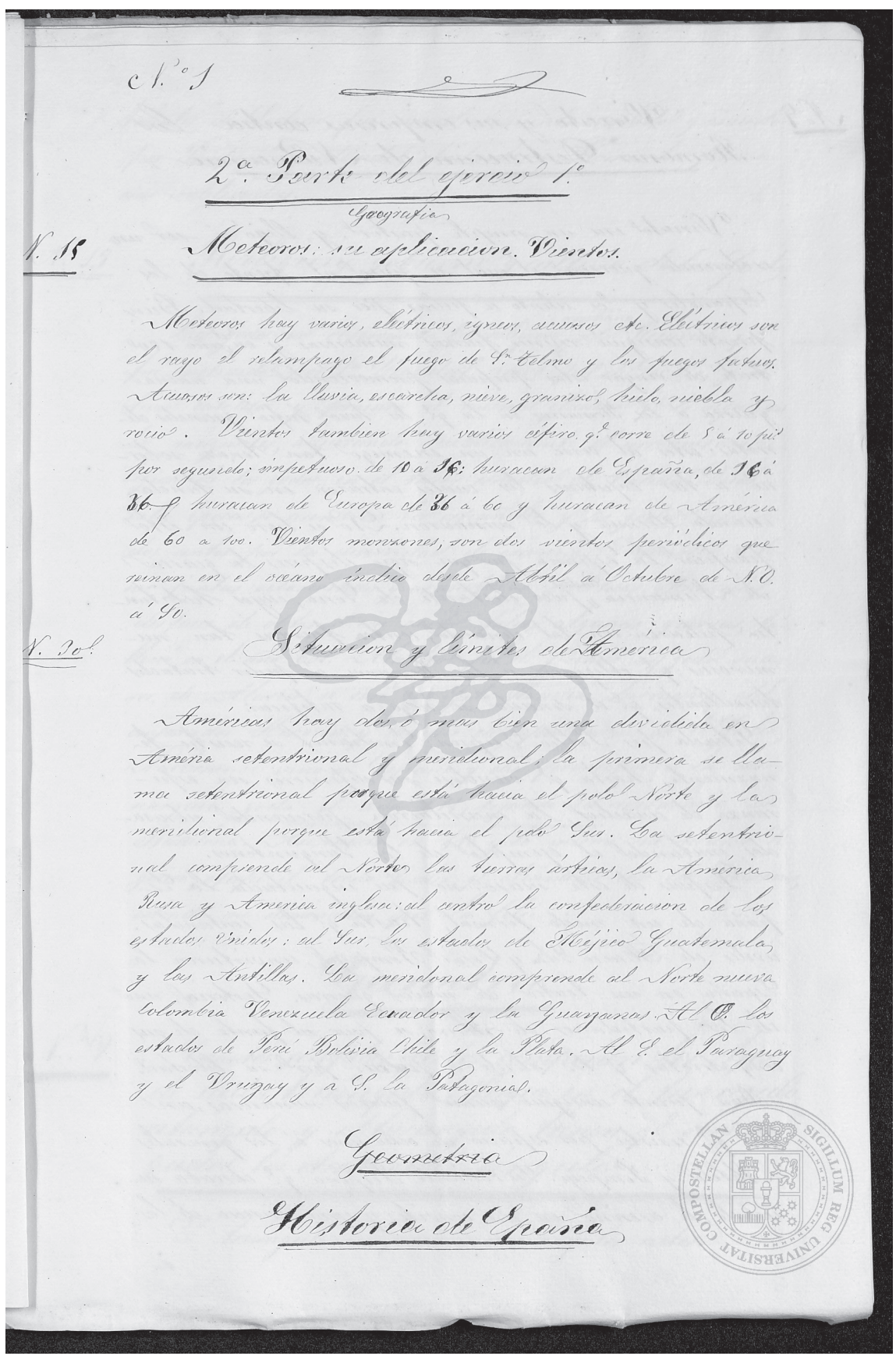




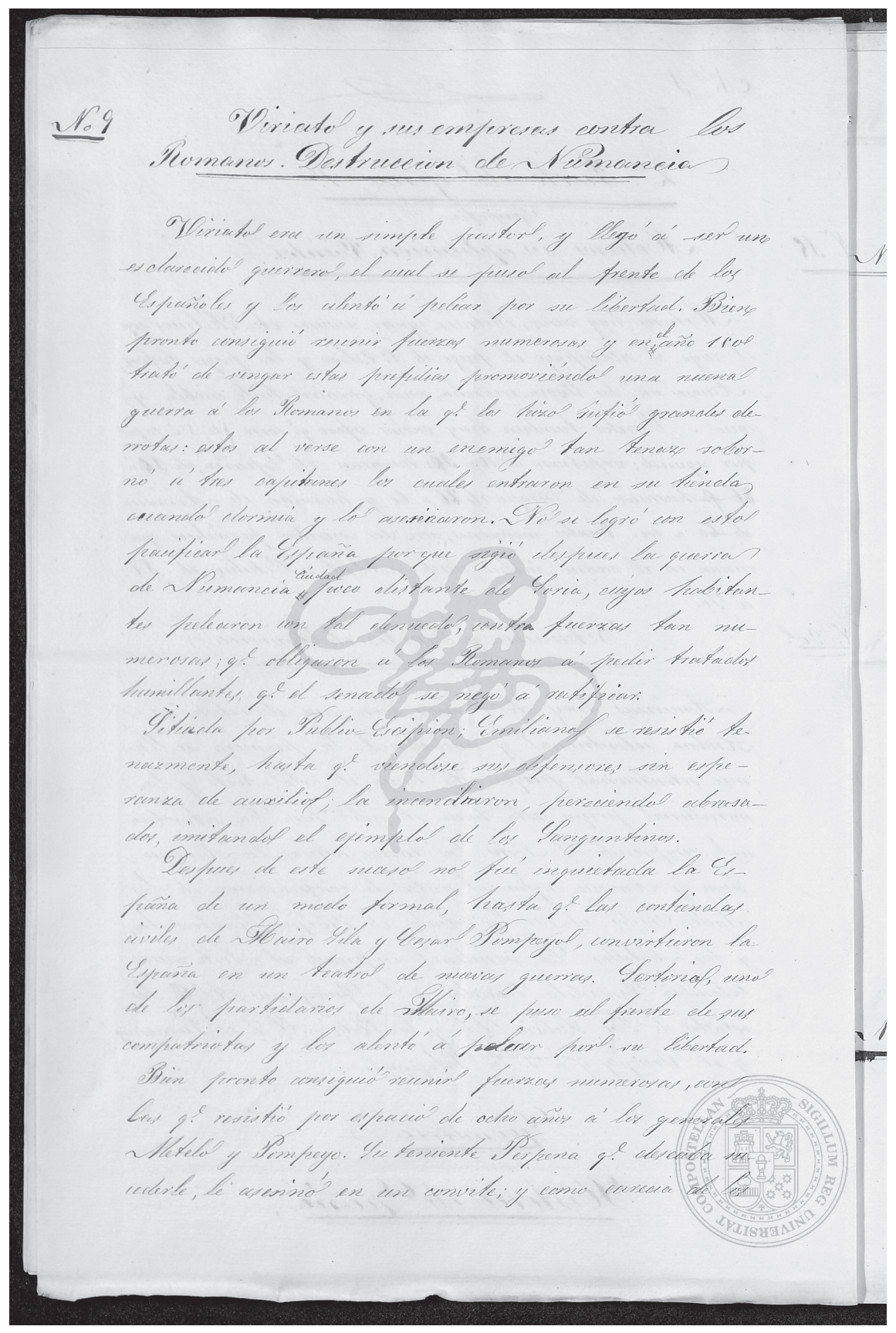




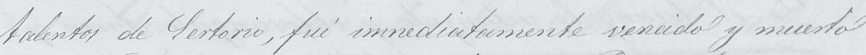

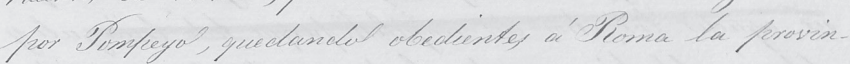

N.S.3

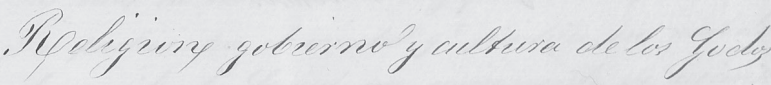

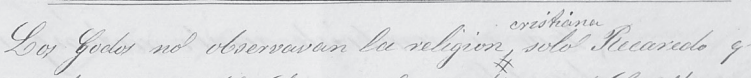

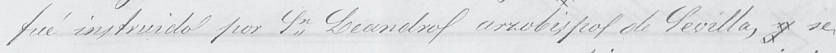

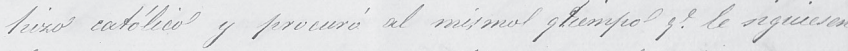

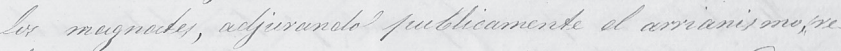

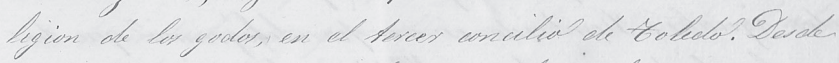

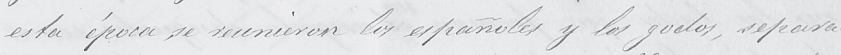

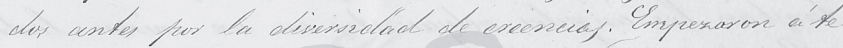

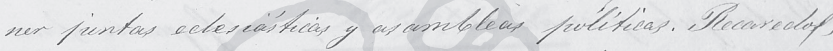

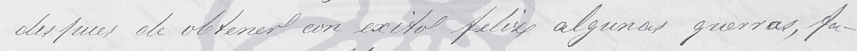

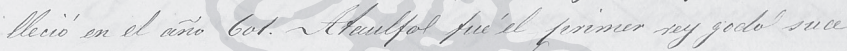

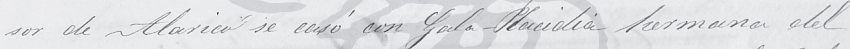

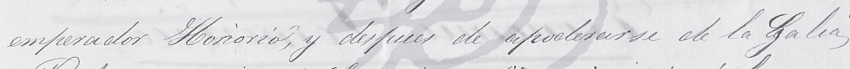

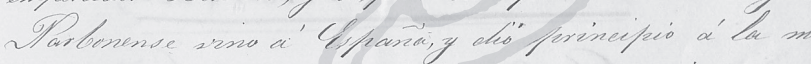

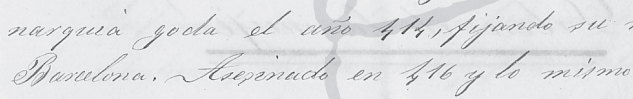

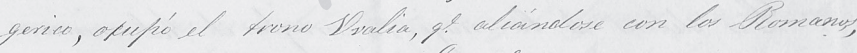

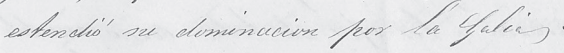

\section{Georredicia}

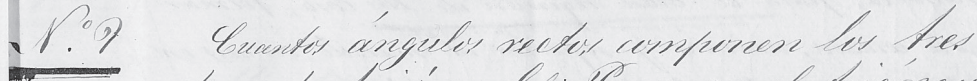

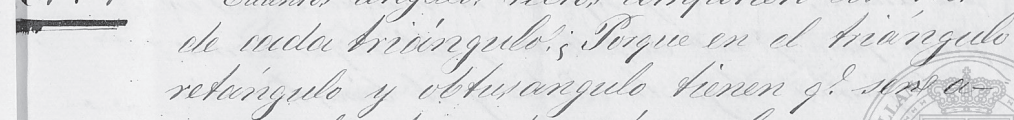

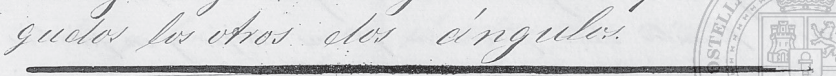

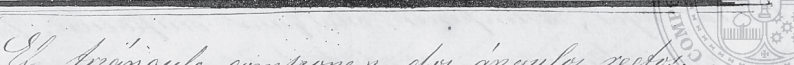

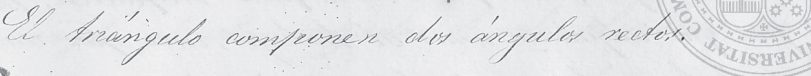
. 


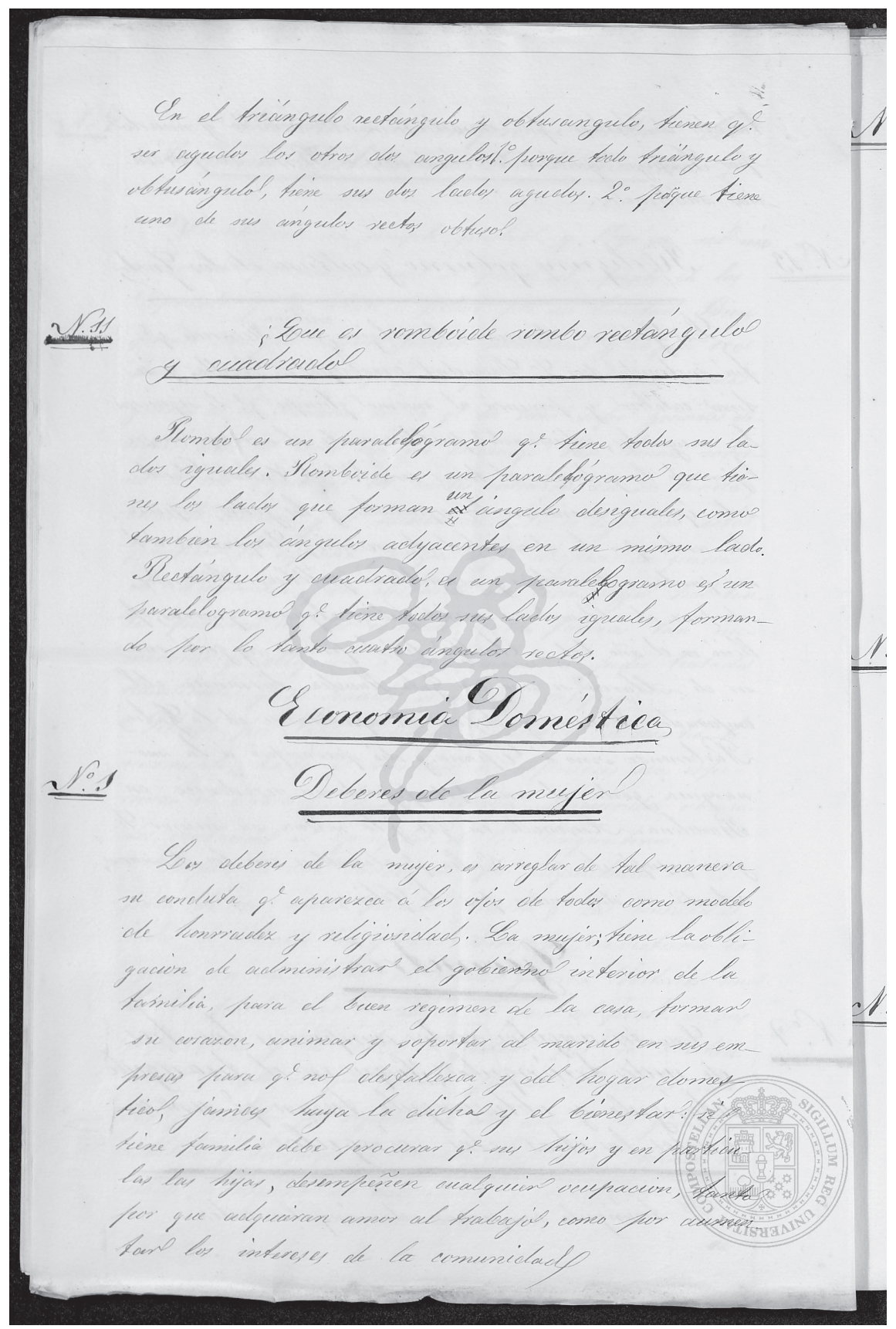




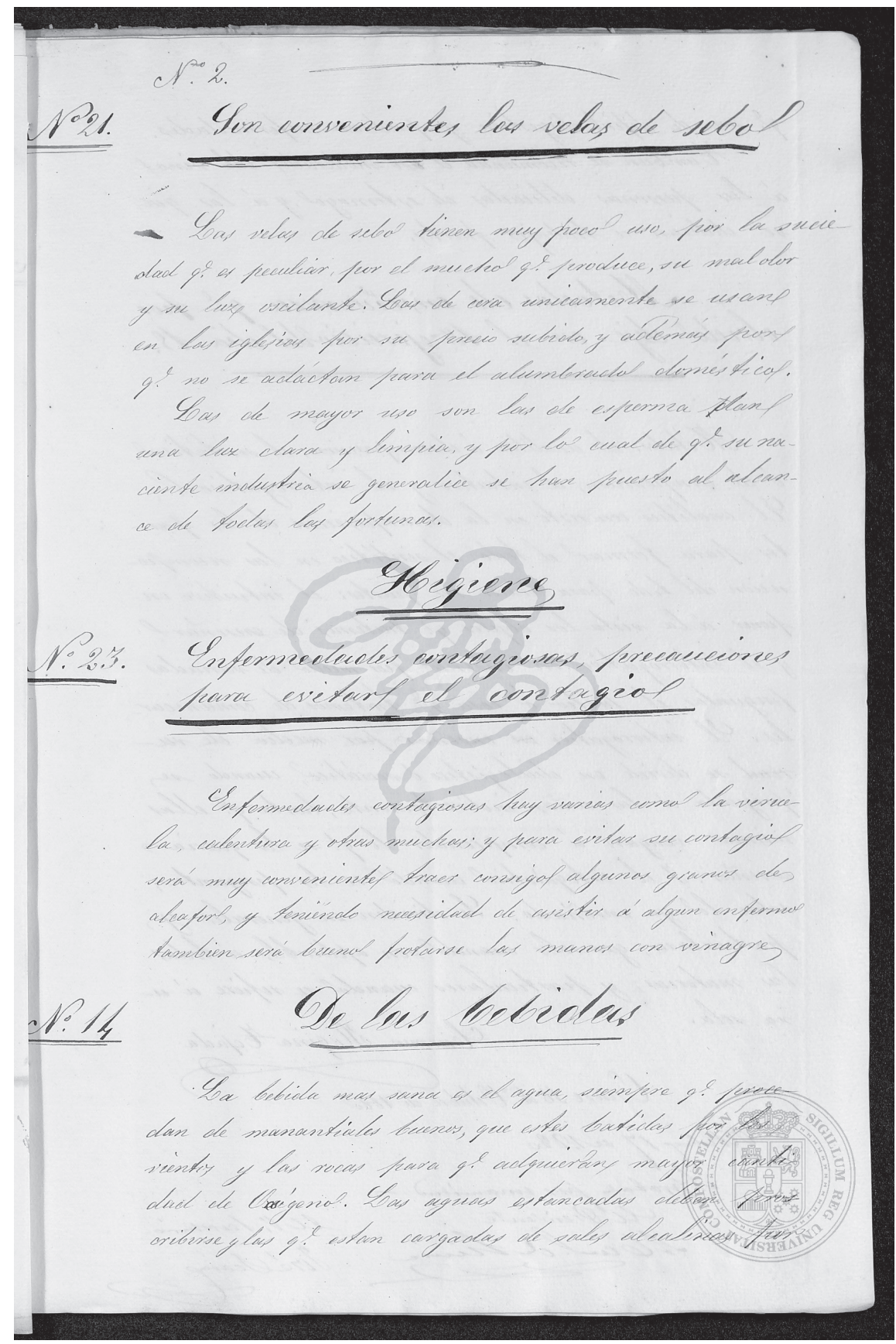




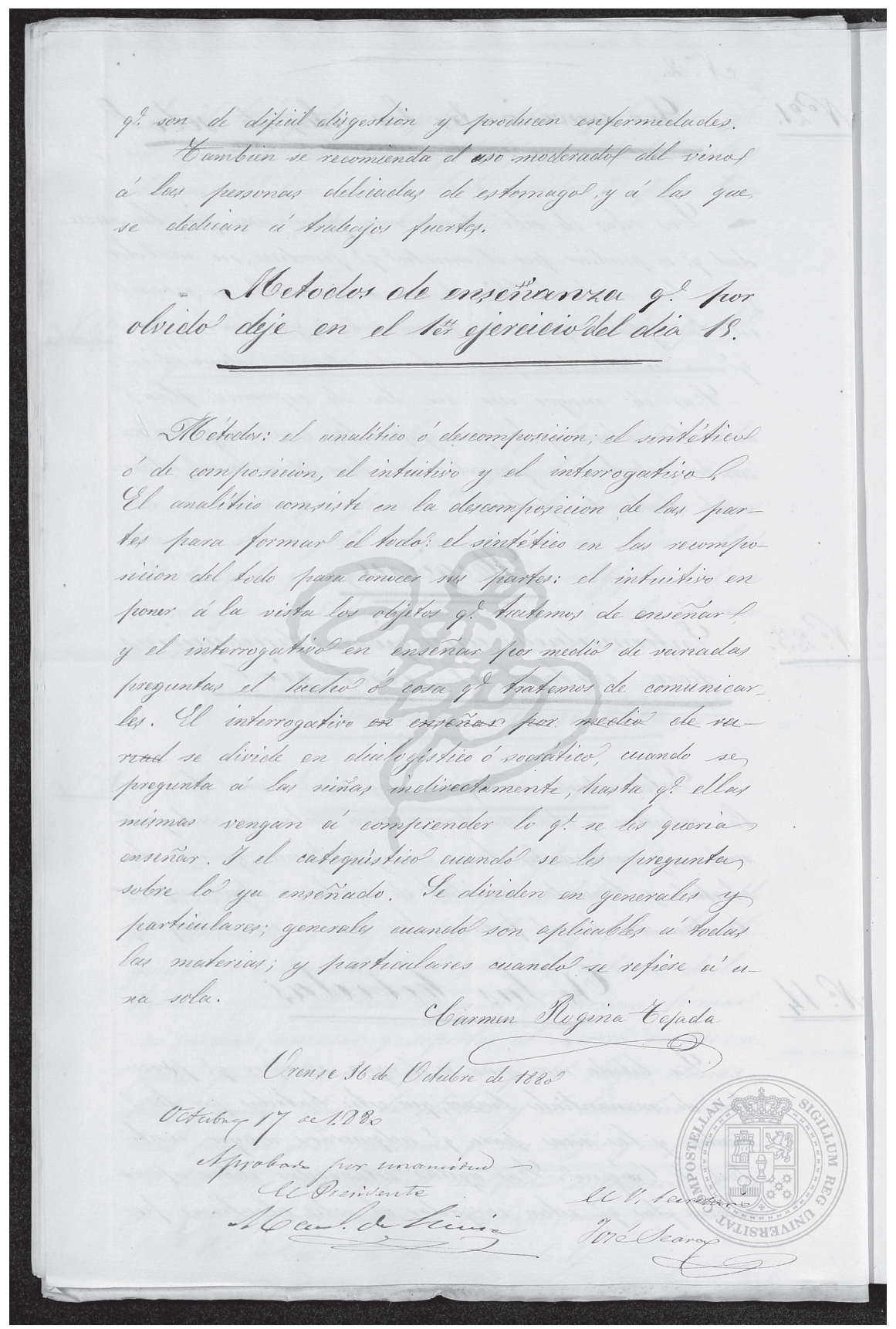




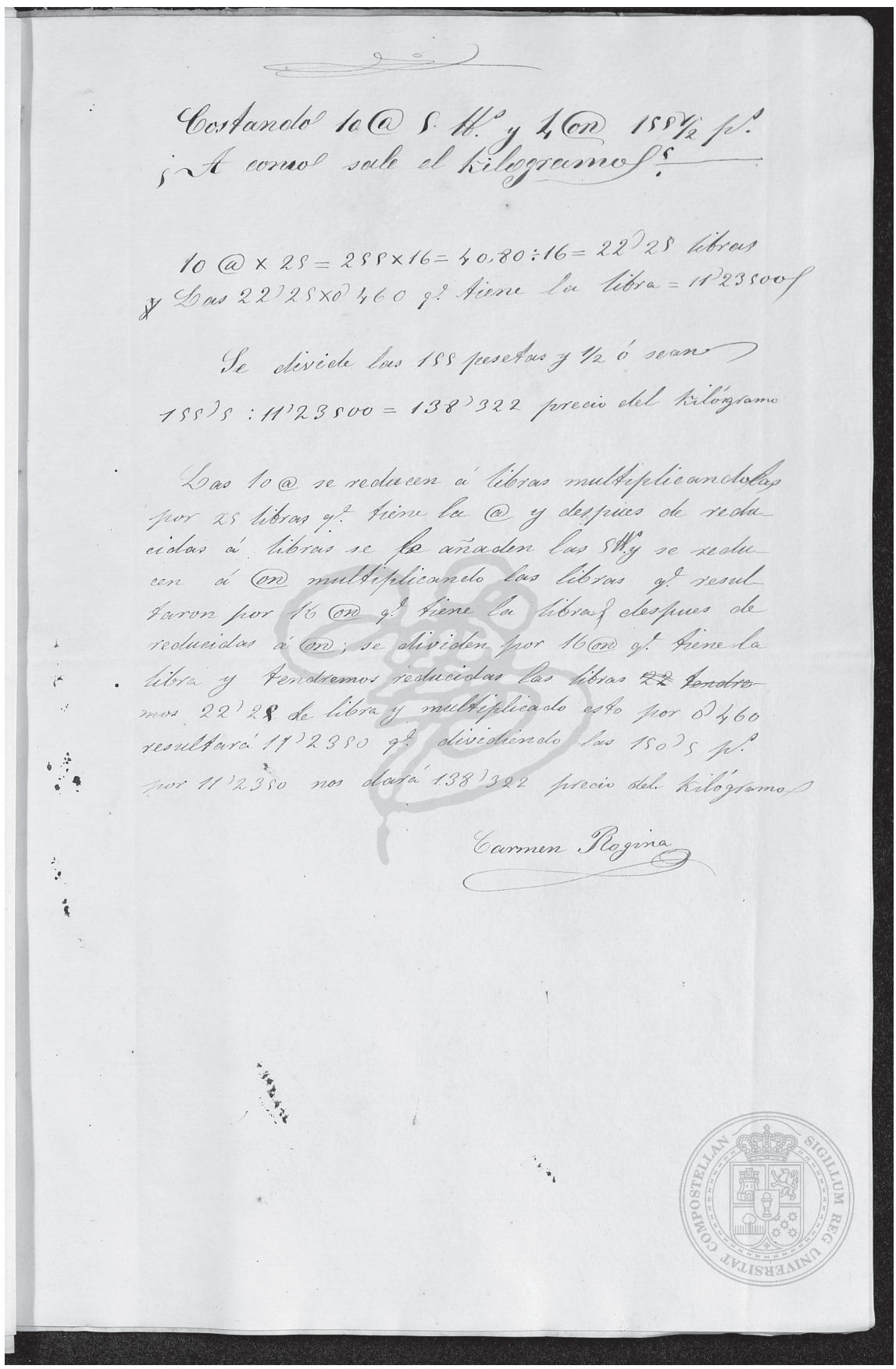


whrdetohieflimnopipistux y:.

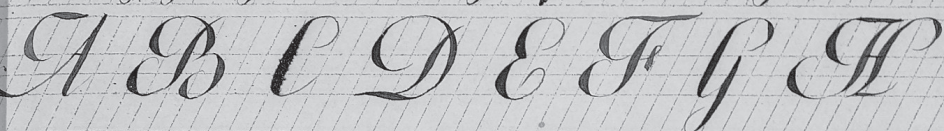

*ch chomo

ip $40 \%$

o. Carmin choginin o. Cu.

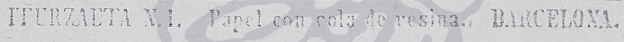




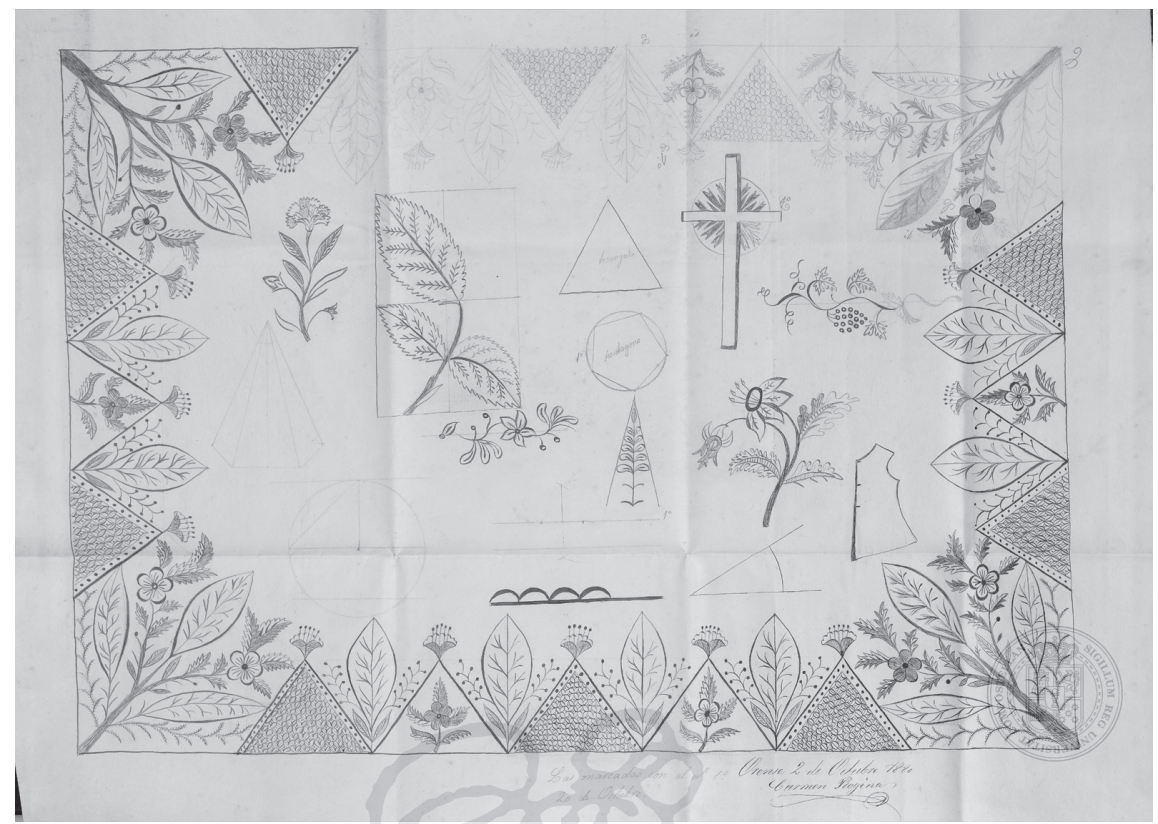

